\title{
VDH - a case of ostrich philosophy or a serious alternative for the disposal of highly radioactive waste?
}

\author{
R. Pusch, M. H. Mohammed \& S. Knutsson \\ Luleå University of Technology, Sweden
}

\begin{abstract}
Two basically different concepts for the disposal of highly radioactive waste are the often cited KBS-3 method implying isolation of such waste in copper canisters in short holes bored from tunnels at a depth of a few hundred meters, and disposal in the lower part of $4 \mathrm{~km}$ deep holes (VDH). The deep hole concept has the advantage that the waste packages will be located in very salty, stagnant groundwater in rock that is much less permeable than shallow rock with repositories of KBS-3V type. The disadvantages are that some of the techniques for installation have not yet been demonstrated and that the retrieval of damaged or stuck canisters is deemed more difficult than for KBS-3V. Both concepts require precise adaption of canister and seal positions to the rock structure, which, for KBS-3 repositories, is not known until the tunnels have been constructed. For VDH, pilot borings provide such knowledge at low cost at a very early stage. The deep holes need to be supported by casings and all work deeper than $500 \mathrm{~m}$ must be made with clay mud in them. Reconsideration of the design and function of VDH shows that it has significant advantages, primarily respecting cost and construction time, and that new types of concrete for sealing purposes can make such repositories safer than KBS-3V disposal since seismic and tectonic events are less detrimental and future glaciations will cause much less disturbance. The most important value is that the groundwater that can possibly become contaminated by failing engineered barriers will stay at more than $2000 \mathrm{~m}$ depth and that there is no mechanism that can bring it up to the biosphere.

Keywords: clay, concrete, disposal of radioactive waste, deep boreholes.
\end{abstract}




\section{Introduction}

Underground repositories for disposal of highly radioactive waste (HLW) consist of deposition tunnels and holes in which containers (canisters) are installed (fig. 1). The most rational way of utilizing the host rock is to put several canisters in long holes (A and D in fig. 1) but placement in short boreholes extending from blasted tunnels is an alternative if the number of canisters per disposal campaign is limited. Placement of canisters below a few thousand meters in steep holes (VDH) has the advantage that groundwater that can possibly become contaminated by radionuclides from leaking engineered barriers will be maintained there for density reasons.

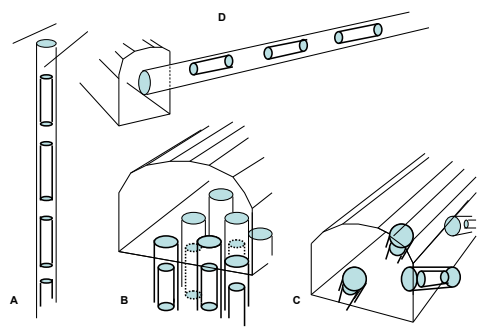

Figure 1: $\quad$ Four repository concepts for crystalline rock. Small cylinders in bigger ones represent HLW canisters surrounded by buffer clay and placed in deposition holes. The leaning of holes as in $\mathrm{C}$ gives favourable rock stability conditions.

\section{Medium-deep disposal}

Several comprehensive studies like EU's CROP project [1] have been conducted for assessing the capacity of proposed repository concepts to isolate HLW from the biosphere. The major conclusions were that different geological media - crystalline rock, salt, and argillaceous rock - have advantages and disadvantages in various respects and that disposal in crystalline rock requires more effective engineered barriers than the others because of its higher permeability. However, crystalline rock provides more stable conditions than the others and is presently a primary candidate for hosting repositories in Sweden, Finland and Canada. Testing of rock and engineered barriers (EBS) in mined underground laboratories (URLs) has shown that they perform according to expectations and represent a large enough variety of conditions for providing a basis for predicting their function over longer periods of time. Commonly proposed depths for locating a repository of one-level type is 400-600 m. Access to the repositories is through shafts and tunnels.

As to the host rock three major factors are essential: 1) the structure on large and small scales because it controls the impact on the repository of earthquakes and tectonic movements, 2) the groundwater flow, and 3) the impact of the 
physical and chemical performance on the engineered barriers. These are metal canisters containing the waste (spent fuel or vitrified, processed waste), and clay - termed buffer - surrounding the canisters for minimizing groundwater flow in their vicinity and for providing ductile embedment of the canisters (fig. 2). The waste generates a heat pulse that lasts for several hundred years and that can strongly affect the function of the barriers and the groundwater flow, as well as the stress conditions in the rock, and thereby its physical stability.

We will take here the Swedish KBS-3V repository concept to represent disposal at moderate depth, i.e. 400-500 m (fig. 2). The rock stresses are commonly too high to construct repositories by use of ordinary techniques, blasting or TBM-boring, deeper than that. The figure illustrates two difficulties with this concept, firstly the problem of locating the individual deposition holes with about $1.9 \mathrm{~m}$ diameter and $8 \mathrm{~m}$ depth so that shearing of persisting discontinuities in the rock will not damage the canisters, and secondly to choose a tunnel backfill that can resist upward movement of the canisters, driven by expanding buffer, which will otherwise cause axial tension stresses in them.

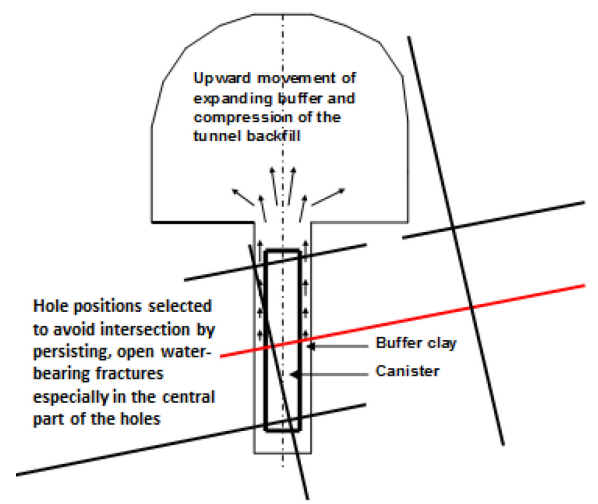

Figure 2: Section of KBS-3V deposition tunnel with deposition hole intersected by persisting discontinuities in the form of fractures that can undergo shearing caused by rock displacements. Arrows indicate upward expansion of the canister-embedding buffer by displacing too soft tunnel backfill.

The general plan of utilizing the rock is illustrated by fig. 3, which shows the principle of adapting the positions of the deposition holes to major rock structural features.

Positioning of deposition holes, which are about $1.9 \mathrm{~m}$ in diameter and $8 \mathrm{~m}$ deep, cannot be made until the planned repository level has been reached $[1,2]$. After constructing the tunnels, which will provide rich information on the rock structure, slim pilot holes will be drilled in different directions for general exploration and rock categorization. A few holes with 3-400 m length drilled within the $20 \mathrm{~m}^{2}$ section of forthcoming tunnels will reveal the presence and orientation of fracture zones ( $3^{\text {rd }}$ order zones in fig. 3$)$ and give a first indication of whether the plan is worth pursuing. A large number of deposition hole positions in the finally constructed tunnels must be investigated for making sure that none of them will be intersected by unsuitably located persistent water- 
bearing fractures before the entire repository design can be decided. Preparative work also comprises determination of the compressive strength of the rock matrix and of the shear strength of major fractures for predicting the mechanical stability of the rock.

The site investigation and design work will take at least a decade for a repository with 6000-7000 canisters and will ultimately provide plans of the type shown in generalized form in fig. 3. The degree of utilization is commonly expected to be $50-60 \%$, representing the percentage of useful hole positions [2, 3]. Full-face boring of deposition holes will be made by using TBM-type technique causing an excavation-induced disturbed zone (EDZ) of a couple of centimeters. The EDZ of blasted tunnels ranges between a few decimetres and two meters $[1,2]$.

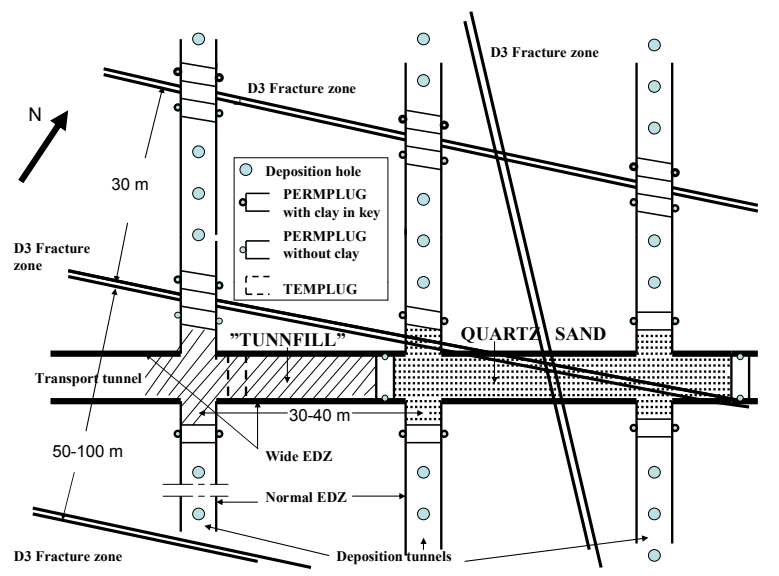

Figure 3: $\quad$ Schematic plan view of a KBS-3V repository with a transport tunnel connected to deposition tunnels in rock with typical frequency of minor fracture zones (D3). Tight bulkheads are keyed into the rock for isolating the waste-containing parts of the deposition tunnels from adjacent rooms and tunnels [2].

\section{Deep disposal}

The deep hole concept considered here (VDH) implies waste placement in the lower $2 \mathrm{~km}$ part of $4 \mathrm{~km}$ deep holes and effective sealing of the upper $2 \mathrm{~km}$ (fig. 4), [4, 5]. Several holes will be bored in slightly different directions from a chamber near the ground surface for avoiding overlap of temperature fields. While it may well be possible to make stable large-diameter boreholes to $4 \mathrm{~km}$ depth extra support in the form of casings in the larger part of the steeply oriented holes is recommended.

The location of the holes is decided on the basis of the structural constitution of the rock, especially the presence and orientation of fracture zones based on rock characterization using a number of slim steep and graded holes bored in the 
selected host rock regions. The preparative work includes determination of the compressive strength of the rock matrix and hydraulic characterization of the rock mass by cross-hole measurements.

The site investigation and design work will take at least a decade for 10 to 15 deposition holes in each of 5 to 10 sites for hosting the same amount of waste as KBS-3V. The degree of utilization of the rock is expected to be $50-60 \%$. Boring of deposition holes will be made by using oil-drilling techniques with smectitic boremuds. The EDZ of the holes is less than for the KBS-3V deposition holes except where they intersect fracture zones, which have to be stabilized and tightened by grouting [5].

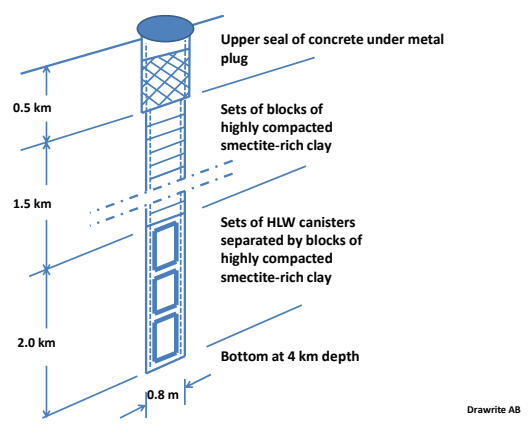

Figure 4: $\quad$ VDH with constant diameter below the uppermost $0.5 \mathrm{~km}$ concrete fill, below which the hole is tightly sealed with clay and concrete to $2 \mathrm{~km}$ depth. The "disposal" zone with sets of connected HLW canisters separated by clay blocks is shown here in a hole with 0.8 $\mathrm{m}$ diameter [5].

\section{The role of the rock}

When the issue of working out plans for safe disposal of HLW became urgent some decades ago most investigators preferred to apply the multi-barrier principle taking the repository host rock as the first and most important barrier to contamination of the groundwater with radionuclides, and appointing engineered barriers as redundant seals of less importance. When national legislation required isolation of HLW for very long periods of time, presently 100000 to 1000000 years, it was realized that tectonic impact, earthquakes and glaciations can largely change the performance of the rock, the ranking was changed and engineered barriers became more important. Today, the primary isolating function is ascribed to the canisters, which has made corrosion of the canister metal and the potential of canisters to resist mechanical impact by rock strain particularly important. For VDH the conditions are different since the major waste-isolating capacity is provided by the heavy groundwater in the lowpermeable rock deeper than $2000 \mathrm{~m}$ [4]. For VDH, retainment of possibly contaminated groundwater at depth is more important than tightness of the canisters. Hence, while the role of the host rock for KBS-3V type repositories is 
primarily to provide mechanical protection of the canisters and surrounding clay buffer, it is to actively hinder possibly contaminated groundwater to reach up to the biosphere for VDH.

\section{For and against KBS-3V and VDH concepts}

\subsection{General}

The KBS-3 concept implies that excavation of shafts, ramps and tunnels takes place under drained conditions at 400-500 $\mathrm{m}$ depth in crystalline rock $[1,2,5]$. The groundwater pressure in the vicinity of the excavated areas drops but is restored in the course of tunnel backfilling, causing problems by erosion and reduced stability. In very tight rock, like the presently proposed Forsmark area in Sweden, it can take hundreds of years before the buffer becomes wetted and this can cause permanent loss of its self-sealing ability. Precipitation of canisterdegrading dissolved matter in the buffer, like sulphides, can take place in this period.

The VDH concept implies that deep holes for waste disposal at 2000 to $4000 \mathrm{~m}$ depth and seals above the $2000 \mathrm{~m}$ level are bored and filled without changing the piezometric conditions. Moderate to low temperatures prevail in the sealed parts of the deep holes, i.e. down to $2000 \mathrm{~m}$, while the temperature can be up to $150^{\circ} \mathrm{C}$ in the lower, waste-bearing part. Wetting of the buffer will take place under high water pressure $(20-40 \mathrm{MPa})$ and is completed in a few years.

A major difference between the two concepts from functional viewpoints is that a KBS-3V repository has a largely continuous EDZ acting as a major groundwater flow path, while a VDH disposal site has no such defect.

\subsection{Problems and risks with KBS-3V and VDH}

\subsubsection{Rock stability}

At $400-500 \mathrm{~m}$ depth the primary rock pressure is commonly up to $30-50 \mathrm{MPa}$ and the hoop stress can be critical for certain geometries. Fig. 5 illustrates their effect on the rock stresses at the top and half-height of the KBS-3V deposition holes. The primary maximum principal stress is taken as $30 \mathrm{MPa}$ and the lowest as $10 \mathrm{MPa}$, oriented vertically. The primary intermediate principal stress is assumed to be $15 \mathrm{MPa}$. The related hoop stresses of the deposition holes are summarized in Table 1 for two calculation methods, 3DEC used by Clay Technology AB, Sweden, and BEASY used by Computational Mechanics Centre at Southampton, UK [3].

Table 1: Hoop stresses in MPa of KBS-3V deposition holes [3].

\begin{tabular}{|l|c|c|c|c|c|}
\hline Case & Code & A & B & C & D \\
\hline V1 & 3DEC & 165 & 20 & 80 & 18 \\
\hline V1 & BEASY & 184 & 25 & 85 & 20 \\
\hline V2 & 3DEC & 53 & 63 & 22 & 72 \\
\hline
\end{tabular}


The unconfined compressive strength is taken here as $175 \mathrm{MPa}$, which means that the V1 case can be critical, while orienting the tunnels to be parallel with the major principal stress reduces the hoop stress to 50-60 $\mathrm{MPa}$. Since the orientation of stress fields often varies considerably one has to consider the possible case with the major principle stress oriented 450 off the V2 orientation. It gives a maximum hoop stress of $115 \mathrm{MPa}$, implying a safety factor of 1.52. SKB later made additional calculation of the hoop stress taking the impact of heat from the radioactive decay into consideration and found that all the holes will fail [6]. The rock will break and can be expected to be richly fractured as indicated in fig. 6. Failure will cause a pervious zone around the holes that is connected to the significantly water-bearing EDZ around the tunnels.

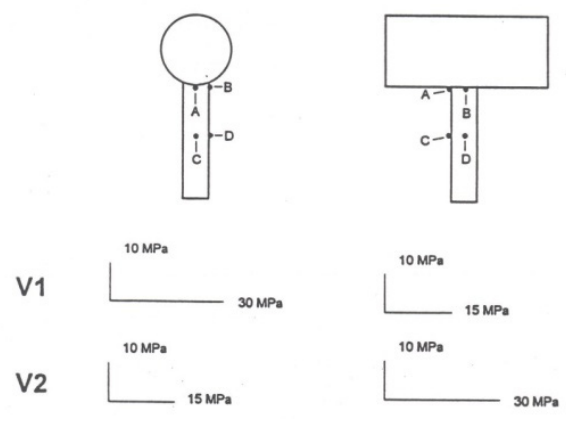

Figure 5: The hoop stress of KBS-3V holes for two primary rock stress conditions: V1 with the maximum horizontal principal stress oriented perpendicularly to the tunnels, and V2 with the tunnel rotated $90^{\circ}$ off the $\mathrm{V} 1$ direction.

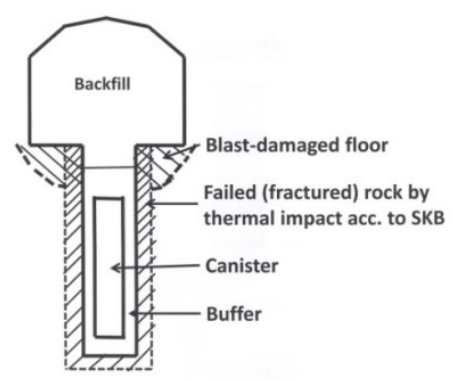

Figure 6: Pervious zone around the deposition holes by overstressing the rock.

For VDH the stability conditions are different because of the higher stresses. Using data bases and generalized relationships between depth and stress states [3] the maximum and minimum horizontal stresses can be estimated at 56 
$\mathrm{MPa}$ and $39 \mathrm{MPa}$ at $2 \mathrm{~km}$ depth, but higher pressures have been recorded at this depth as in the $6 \mathrm{~km}$ deep German KTB hole [5]. Here, the maximum horizontal stress was found to be $70 \mathrm{MPa}$ at a depth of $2 \mathrm{~km}$, and 120 and $\mathrm{MPa}$ at $4 \mathrm{~km}$ depth. High pressures have also been reported from measurements at $3 \mathrm{~km}$ depth in crystalline rock as in the Nojima fault in Japan where the maximum and minimum horizontal stresses were 88 and $64 \mathrm{MPa}$, respectively [5]. Assuming, for a forthcoming VDH in Sweden, the same stresses as in the German KTB hole the hoop stress of a bored hole would be up to $100 \mathrm{MPa}$ at $2 \mathrm{~km}$ depth and 190 $\mathrm{MPa}$ at $4 \mathrm{~km}$ depth. No correction for the impact of winding stress directions would be necessary below $2 \mathrm{~km}$ since the variation in orientation of principal stresses is reported to vary only within $10 \%$ [5].

As for the KBS-3V thermal stresses will add to the pressure in the deployment part but to a lesser extent because of the much smaller temperature rise. In $4 \mathrm{~km}$ deep holes the ambient temperature is expected to be about $64^{\circ} \mathrm{C}$ [5]. For two investigated canister configurations, one with 4 BWR spent fuel elements and one with $2 \mathrm{BWR}$ and $1 \mathrm{PWR}$, the heat production would give a net temperature of $90^{\circ} \mathrm{C}$ at $2 \mathrm{~km}$ depth and $150^{\circ} \mathrm{C}$ at $4 \mathrm{~km}$ depth assuming generally accepted data of the heat generation and thermal properties of the engineered barriers and the rock [5]. The essential difference between the two concepts is that the stability of the deep vertical VDH with $800 \mathrm{~mm}$ diameter becomes acceptable by using a dense deployment mud, serving also as drilling mud, while that of KBS-3V holes will be insufficient soon after placement of the canisters. The impact on the maximum radial stress by the mud is demonstrated by inserting the depth-dependent mud pressure in the classical Kirsch equations, leading to the expression for the hoop stress:

$$
\sigma_{\theta}=\left(\sigma_{H}+\sigma_{h}\right)-2\left(\sigma_{H}-\sigma_{h}\right) \cos \theta-\mathrm{g} \rho z
$$

where $\sigma_{\mathrm{H}}$ and $\sigma_{\mathrm{h}}$ are the major and minor horizontal stresses, $\theta$ the angle between the considered plane and the plane in which the major horizontal stress is located, $\rho$ the density of the mud, $\mathrm{g}$ the coefficient of gravity, and $\mathrm{z}$ the depth.

Water-filled holes would stay intact to $2 \mathrm{~km}$ depth since the hoop stress here, i.e. about $100 \mathrm{MPa}$, is significantly lower than the assumed compressive strength $175 \mathrm{MPa}$. At $4 \mathrm{~km}$ depth a significant fraction of the $2-4 \mathrm{~km}$ deep part of a water-filled VDH would fail since the hoop stress would be $208 \mathrm{MPa}$, but filling it with clay mud weighing $1600 \mathrm{~kg} / \mathrm{m}^{3}$ would reduce the hoop stress to $168 \mathrm{MPa}$ at this level and to $85 \mathrm{MPa}$ at $2 \mathrm{~km}$ depth. This would give sufficient stability but use of casings in the deployment zone is a recommended additional safety measure.

\subsubsection{Engineered barriers}

The multibarrier concepts KBS-3V and VDH rely to some extent on the rock as natural barrier but more on man-made barriers: canisters with HLW and clay surrounding them, and clay and concrete for sealing shafts and holes reaching down to the waste. The temperature to which the barriers will be exposed can be up to $100^{\circ} \mathrm{C}$ for $\mathrm{KBS}-3 \mathrm{~V}$ and $150^{\circ} \mathrm{C}$ for $\mathrm{VDH}$, which can change their waste-isolating capacity. 
5.2.2.1 Canisters The presently favoured KBS-3V canister consists of cast iron with 12 BWR elements of spent fuel, lined by $50 \mathrm{~mm}$ copper $[1,2,7]$, and the latest VDH canister type, favoured by the present authors, is of the same type but with only 4 BWRs. The outer diameter of the KBS-3V canister is $1050 \mathrm{~mm}$ and the height $4850 \mathrm{~mm}$, its weight being $24500 \mathrm{~kg}$. The VDH canister, fitted in dense buffer clay in perforated supercontainers, is proposed here to have $500 \mathrm{~mm}$ diameter and $4850 \mathrm{~mm}$ height, weighing about $6000 \mathrm{~kg}$. The casing is proposed to be made of an alloy of Navy Bronze, consisting of more than $90 \%$ copper and about $10 \%$ nickel for fulfilling the criterion of mechanical strength and chemical compatibility $[2,7]$.

A small fraction of the canisters will have defects from start and leak, which contaminates the surrounding clay and the surrounding rock with radionuclides. Depending on the degree of ductility of the clay, thermally or seismically generated displacements in the rock will be transferred to the canisters that may ultimately fail [2]. Water will migrate into the canisters and make the iron core corrode and produce highly pressurized hydrogen gas that penetrates the surrounding clay channel-wise and migrate further along the rock contact or within the rock. The canisters in a KBS-3V repository will be exposed to tension caused by upward expansion of the buffer clay (fig. 2). This movement can be very significant depending on the compressibility of the overlying tunnel backfill and cause breakage at the junction of copper liner and lid and speed up corrosion. VDH canisters of the same type will be under high isostatic pressure but there will be no tension.

5.2.2.2 Clay buffer Clay serves as a very effective sealing component in both concepts by retarding groundwater flow around and along the canisters and by providing a homogeneous ductile embedment of the canisters [1, 2, 7]. For KBS-3V the clay surrounding the waste containers is proposed by SKB to be a smectite-rich clay consisting primarily of montmorillonite. For the VDH concept there are two clay components of the same type as for KBS-3V but placed with different densities, i.e. the mud, and the compacted blocks of KBS-3V buffer type.

The physical and chemical evolution of the buffer clay in KBS-3V is different from that of the mud and dense clay in VDH. For the firstmentioned the water pressure will be relatively low and the inflow into the deposition holes low, which can delay water saturation by tens to hundreds of years. During this period the desiccated clay is exposed to at least $100^{\circ} \mathrm{C}$ and salt enrichment, dissolution and precipitation processes on the microstructural scale can reduce the expandability and self-healing ability of the ultimately water saturated clay, and also make it stiffer $[2,7,8]$.

In the upper, sealed part of the $\mathrm{VDH}$ the temperature will range from about $15^{\circ} \mathrm{C}$ to $60^{\circ} \mathrm{C}$ causing no heat-induced changes and providing total tightness directly after installation. In the deployment part, which will be heated up to $150^{\circ} \mathrm{C}$, mineralogical changes and less good isolation are expected as realized by considering fig. 7. Montmorillonite is converted to (non-expansive) illite via mixed-layer smectite/illite minerals or precipitation, and quartz is formed at a 
rate determined by the access to potassium and temperature [2]. Cementation is caused by precipitation of neoformed quartz and illite. Natural analogues from various parts of the world indicate that Tertiary and Ordovician bentonites exposed to about $130-160^{\circ} \mathrm{C}$ for a few thousand years have a significant part of their montmorillonite content preserved, and this is expected to be the case for KBS-3V and VDH $[1,2,7,8]$. They are all, however, more or less cemented.

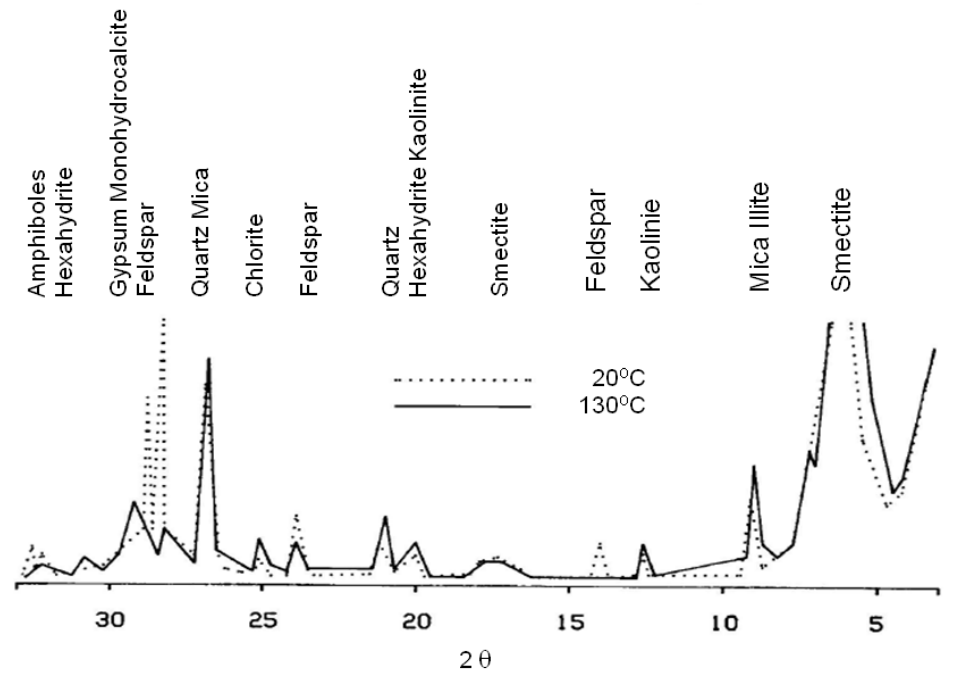

Figure 7: Schematic diffractograms of a montmorillonite-rich reference (MX-80) sample $\left(20^{\circ} \mathrm{C}\right)$ and of the most heated part of a hydrothermally tested sample $\left(130^{\circ} \mathrm{C}\right)$. Feldspars, amphibole, some of the quartz and smectite disappeared in the hot part [2].

In all parts of VDH the clay blocks are quickly water saturated under the prevailing high water pressure. The ultimate density of the clay blocks in both the KBS-3V and VDH repositories will be 1900 to $2000 \mathrm{~kg} / \mathrm{m}^{3}$, which gives the clay a hydraulic conductivity of no more than E-11 m/s at saturation with Ca-dominated water, and a swelling pressure of at least $1 \mathrm{MPa}$ [2]. Over the larger part of the length of the supercontainers (fig. 8) containing HLW canisters the density of the mud will remain unchanged at $1600 \mathrm{~kg} / \mathrm{m}^{3}$ (dry density $950 \mathrm{~kg} / \mathrm{m}^{3}$ ) but the physical properties will change, implying an increase in hydraulic conductivity and a drop in swelling pressure $[2,7,8]$.

The chemical evolution of the clays in both repository concepts depends on the temperature and salt concentration in the groundwater as well as on the interaction with the canisters, supercontainers and casings. Some minor exchange of the initially sorbed sodium ions by copper ions will take place but $\mathrm{Ca}$, the dominant cation in strongly brackish KBS-3V groundwater and in very salt groundwater $(>10 \mathrm{~g} / \mathrm{l})$ in deeper parts of a VDH [5], will control the microstructural constitution and thereby the physical properties. 
Exposure of water-saturated montmorillonite-rich clay to strong gamma radiation and $90-135^{\circ} \mathrm{C}$ temperature has no particular degrading impact but speeds up dissolution and can cause cementation by precipitation of ion complexes at cooling [2]. This is witnessed by the stiffening recorded at 1 year long hydrothermal tests [2].

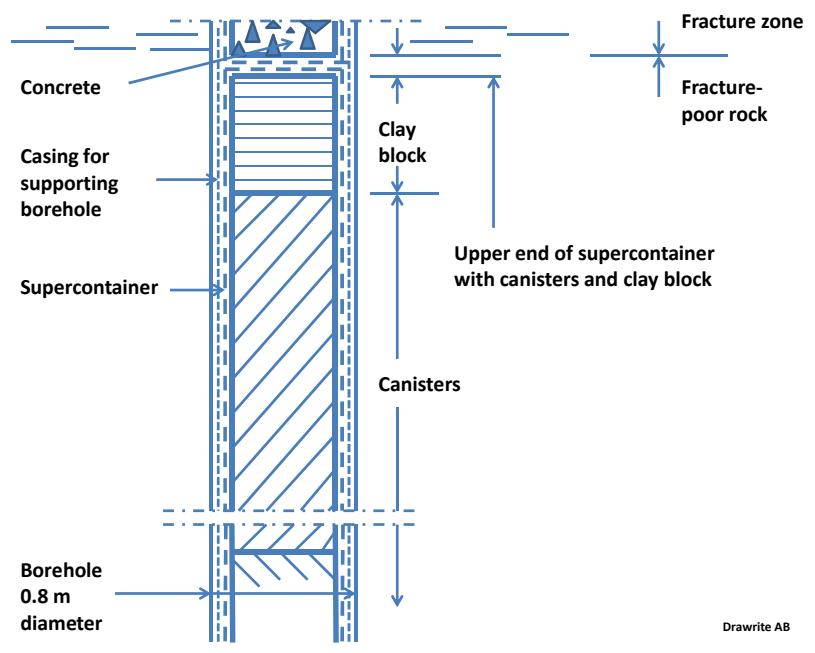

Figure 8: Supercanisters in the deployment zone. The VDH has $0.8 \mathrm{~m}$ diameter and the supercontainer $0.70 \mathrm{~m} \mathrm{[5].} \mathrm{The} \mathrm{casing} \mathrm{surrounds}$ the supercontainer, which is tightly filled with a dense clay block and the $0.50 \mathrm{~m}$ canister. The same type of supercontainer is used also in the upper sealed zones but here they are filled with dense clay blocks.

Modelling of the mineralogical changes in montmorillonite according to Grindrod and Takase [2] has been used for determining dissolution and precipitation of phyllosilicates by taking $\mathrm{O}_{10}(\mathrm{OH})_{2}$ as a basic unit. It defines a general formula for smectite (S) and illite (I) as:

$$
\mathrm{X}_{0.35} \mathrm{Mg}_{0.33} \mathrm{Al}_{1.65} \mathrm{Si}_{4} \mathrm{O}_{10}(\mathrm{OH})_{2} \text { and } \mathrm{K}_{0.5-0.75} \mathrm{Al}_{2.5-2.75} \mathrm{Si}_{3.25-3.5} \mathrm{O}_{10}(\mathrm{OH})_{2}
$$

where $\mathrm{X}$ is the interlamellar absorbed cation (Na) for $\mathrm{Na}$ montmorillonite. According to the model the rate of the reaction $\mathrm{r}$ can be expressed as:

$$
\mathrm{r}=\mathrm{A} \exp (-E a / \mathrm{RT})\left(K^{+}\right) \mathrm{S}^{2}
$$

where: $\mathrm{A}=$ coefficient, $E a=$ activation energy for the conversion of montmorillonite to illite $(\mathrm{S} / \mathrm{I}), \mathrm{R}=$ universal gas constant, $\mathrm{T}=$ absolute temperature, $K^{+}=$potassium concentration in the porewater, and $\mathrm{S}=$ specific surface area. 
This model shows that silica will be released and transported from the hottest to the coldest part of the KBS-3V clay buffer [2]. Thus, assuming a linear temperature drop with time to $25^{\circ} \mathrm{C}$ after 10000 years, silicification and illite formation would be initiated after 500 years, the firstmentioned primarily within about $0.1 \mathrm{~m}$ from the rock, and the latter occurring in the hotter part $\left(60-100^{\circ} \mathrm{C}\right)$.

For VDH the mineralogical stability of the sealed upper part is the same as for $\mathrm{KBS}-3 \mathrm{~V}$, while the mineral content of the mud and clay in the deployment part will be transformed and serve differently with time. Here, the higher temperature accelerates the rates of creation of illite and stiffening will be much higher than for KBS-3V and the colder part of VDH. Thus, using Eq.3 one finds that an increase in clay temperature from 100 to $150^{\circ} \mathrm{C}$ speeds up the rate of converting half the entire original content of montmorillonite to illite by about 100 times, assuming the activation energy to be $27 \mathrm{kcal} / \mathrm{mole}$ and all other factors to be the same. The loss of effective sealing potential will take place in about 100 years but the practical importance is small since the isolating ability of the clay reaction products is still considerable. Thus, for montmorillonite mud converted to pure illite with a density of $1600 \mathrm{~kg} / \mathrm{m}^{3}$ the hydraulic conductivity is still lower than E-8 m/s [5]. Total conversion to non-expandable illite of most of the dense clay in the supercontainers would take 100000 years because the controlling mechanism is diffusive transport of potassium from the surrounding rock [2].

\subsection{Differences in function of KBS-3 and VDH engineered barriers}

The VDH concept discussed here implies that the boring mud is the same as the deployment mud. For serving in the boring phase it must have the required ability to support the hole being bored and to bring up the debris from the boring head. The supercontainers with waste canisters and dense blocks of expansive clay shall sink down or be pushed through the mud to the predetermined levels, which requires that its shear resistance is sufficiently low. This can be done by using equipments like PG-Macs. After installation of the supercontainers with clay blocks or with canisters and such blocks the mud will be consolidated by the expanding dense blocks, which intermittently seal off the holes in the deployment zone, and completely tightens the holes in the upper, sealed part. The performance of the mud in the two parts will be largely different because of the difference in temperature and salt conditions. For the deployment part the only criterion is that the consolidated mud should stay in contact with the rock and canisters for minimizing convective water flow. For the upper sealed part without waste it is required that the expanded clay stays less permeable than the surrounding rock, which is conservatively taken as E- $11 \mathrm{~m} / \mathrm{s}$. This criterion is valid and fulfilled as for the KBS-3V concept.

\section{Summary and conclusions}

The two concepts KBS-3V and VDH are intended for crystalline rock and have similar types of engineered barriers. As to the rock the main difference is that a KBS-3V will be located in permeable rock intersected by frequent fracture zones 
that make the degree of utilization low and the inflow of water strong in the construction phase. VDH disposal makes use of deep, low-permeable rock with stagnant groundwater. This means, in principle, that the rock is a "mechanical protection of the chemical apparatus" for KBS-3V, while, for $\mathrm{VDH}$, the very salt, dense groundwater at depth is a real barrier to migration of possibly released radionuclides.

\subsection{Constructability and cost}

Grouting of intersected fracture zones will be more difficult and less effective for KBS-3V because of the pressure and inflow of water in the construction period. For VDH there are no pressure gradients in axial direction, which simplifies waste installation and casting of concrete seals. The problem with installing canisters in KBS-3V deposition holes is not solved. For VDH the placement of the containers is straightforward but has to be carefully planned with respect to time since expansion of the dense clay in the placement phase increases the resistance to bringing them down [9].

\subsection{Long-term performance}

The evolution of the buffer clay in KBS-3H and VDH is different in a long-term perspective. For the firstmentioned, the low water pressure can make the hydration of the partly desiccated clay very slow, causing salt enrichment and dissolution and precipitation processes that can reduce the expandability and self-healing ability of the clay and also make it stiffer $[2,7]$. In the upper part of a VDH the temperature will range from about $15^{\circ} \mathrm{C}$ to $100^{\circ} \mathrm{C}$ causing no heatinduced changes and providing total tightness early after installation. In the deployment part, which will be heated up to $150^{\circ} \mathrm{C}$, significant mineralogical changes and less effective isolation are expected. Montmorillonite will be partly converted to non-expansive illite via mixed-layer smectite/illite minerals or by neoformation, and quartz will be formed at a rate determined by the temperature [2]. Cementation of the clay microstructure is caused by neoformed quartz and illite. Still, natural analogues indicate that Ordovician bentonites exposed to repository-like conditions with heating to $130-160^{\circ} \mathrm{C}$ for a few thousand years still have a significant part of their montmorillonite content preserved [2]. However, microstructural changes causing increased hydraulic conductivity and stiffening by cementation, reducing the self-sealing capacity, are believed to be significant.

\subsection{Is VDH a case of ostrich philosophy?}

No. We conclude that although both concepts show weaknesses they appear to be qualified for implementation, VDH being the most promising choice. Alternative concepts of similar or higher candidate potential have been described in the literature [7]. 


\section{References}

[1] Svemar, Ch., 2005. Cluster Repository Project (CROP), Final Report of European Commission Contract FIR1-CT-2000-20023, Brussels, Belgium.

[2] Pusch, R., Geological Storage of Radioactive Waste, Springer-Verlag, Berlin and Heidelberg, 2008.

[3] Pusch, R., 1997. Critical positions of canister holes in the Äspö TBM drift, Segment 3510-3600 m. Swedish Nuclear Fuel and Waste Management AB (SKB), Report AR D-98-07, Stockholm, Sweden.

[4] Brady, P., V., Arnold, B., W., Freeze, G., A., Swift, P., N., Bauer, S., J., Kanney, J., L., Rechard, R., P., \& Stein, J., S., 2009. Deep borehole disposal of high-level radioactive waste, SANDIA REPORT 2009-4401, New Mexico/Livermore Calif. USA.

[5] Pusch, R., Ramqvist, G., Kasbohm, J., Knutsson S. \& Mohammed, M. H., The Concept of Highly Radioactive Waste (HLW) Disposal in Very Deep Boreholes in a New Perspective. Journal of Earth Sciences and Geotechnical Engineering, 2(3), pp. 1-24, 2012.

[6] Hakami, E., 2011. Rock stress orientation measurements using induced thermal spalling in slim boreholes. SKB Research Report, R-11-12, Stockholm, Sweden.

[7] Pusch, R., Yong, R. N., Nakano, M., High-level Radioactive Waste Disposal. WIT Press, 2011.

[8] Xiaodong, L. Prikryl, R., Pusch, R., THMC-testing of three expandable clays of potential use in HLW repositories", Applied Clay Science, 52, pp. 419-427, 2011.

[9] Pusch, R., A technique to delay hydration and maturation of borehole seals of expansive clay. Engin. Geol, 121, pp.1-6, 2011. 